\title{
Periodontal-Systemic Disease Education in U.S. and Canadian Dental Schools
}

\author{
Rebecca S. Wilder, B.S.D.H., M.S.; Anthony M. lacopino, D.M.D., Ph.D.; \\ Cecile A. Feldman, D.M.D., M.B.A.; Janet Guthmiller, D.D.S., Ph.D.; Jeffrey Linfante, \\ D.M.D.; Salme Lavigne, R.D.H., B.A., M.S.D.H.; David Paquette, D.M.D., D.M.Sc.
}

Abstract: Research has proliferated in recent years regarding the relationship of oral disease to systemic conditions. Specifically, periodontal disease has been studied as a potential risk factor for multiple conditions such as cardiovascular disease (CVD) and adverse pregnancy outcomes, while other research focuses on exposures or behaviors associated with oral disease. However, few articles have been published reporting how this information is integrated into schools of dentistry, both in the classroom and clinical curriculum. For our study, a thirty-three-item survey and cover letter were electronically mailed to academic deans at sixtyfive accredited dental schools in the United States and Canada in the fall of 2007. The response rate was 77 percent. According to the responses to this survey, the primary topics covered in the didactic curriculum regarding periodontal oral-systemic disease are aging, CVD, diabetes, and tobacco use. Eighty-eight percent of the respondents reported that their students are knowledgeable about the role of inflammation and its impact on oral-systemic conditions. Forty-eight percent of the respondents said they provide formal training for their students in how to discuss or communicate aspects of periodontal oral-systemic disease with patients. Only seven schools reported teaching didactic content to dental students intermixed with other health professions students, and only two schools reported conducting joint projects. Only 9 percent of the respondents said they think nurses and physicians are knowledgeable about oral-systemic disease. The findings indicate that dental schools are confident about the knowledge of their students regarding oral-systemic content. However, much work is needed to educate dental students to work in a collaborative fashion with other health care providers to co-manage patients at risk for oral-systemic conditions.

Prof. Wilder is Associate Professor, Director of Faculty Development, and Director of Graduate Dental Hygiene Education, University of North Carolina at Chapel Hill School of Dentistry; Dr. Iacopino is Dean, University of Manitoba Faculty of Dentistry; Dr. Feldman is Dean, University of Medicine and Dentistry of New Jersey/New Jersey Dental School; Dr. Guthmiller is Associate Dean of Academic Affairs, University of North Carolina at Chapel Hill School of Dentistry; Dr. Linfante is Director of Admissions and Student Recruitment, University of Medicine and Dentistry of New Jersey/New Jersey Dental School; Prof. Lavigne is Professor and Director, School of Dental Hygiene, University of Manitoba Faculty of Dentistry; and Dr. Paquette is Assistant Dean for Graduate Studies and Director of Graduate Periodontology, University of North Carolina at Chapel Hill School of Dentistry. Direct correspondence and requests for reprints to Prof. Rebecca S. Wilder, Graduate Dental Hygiene Education, School of Dentistry, University of North Carolina at Chapel Hill, CB \#7450, Room 3280 Old Dental Building, Chapel Hill, NC 27599-7450; 919-966-8221 phone; 919-966-6761 fax; Rebecca_wilder@dentistry.unc.edu.

Key words: dental education, periodontitis, oral-systemic, dental curricula, interdisciplinary education, curriculum, inflammation

Submitted for publication 6/11/08; accepted 10/27/08

$\mathrm{S}$ ince 1911, when Hunter introduced the concept of the focal infection, interest has varied regarding the impact of an oral infection on distant sites in the body. ${ }^{1}$ In 1989 , a cross-sectional study from Finland provided observational evidence for an association of poor oral health and cardiovascular disease. ${ }^{2}$ Since that time, numerous studies have been conducted to investigate the link between oral and systemic disease, and hundreds of publications have sought to explain the potential relationship.

The infectious and inflammatory burden of periodontal disease has been consistently associated in various populations with diabetes, ${ }^{3-5}$ respiratory diseases, ${ }^{6}$ adverse pregnancy outcomes,${ }^{7,8}$ cardiovascular disease, ${ }^{9-11}$ stroke, ${ }^{12,13}$ kidney disease,${ }^{14}$ obesity, ${ }^{15}$ osteoporosis, ${ }^{16}$ and other chronic conditions. ${ }^{17}$ In addition, the impact of behaviors such as tobacco use on periodontal disease has been extensively studied. ${ }^{18,19}$ Although the science is not conclusive about all relationships between periodontal disease and systemic health, ${ }^{20}$ it is imperative that oral health care providers stay abreast of the latest evidence about periodontal oral-systemic disease connections and potential risk factors as they relate to patient assessment, diagnosis, treatment planning, and referral to dental specialists and medical providers. 
It has been predicted that dentists will need to work more closely with other health care providers in the future to manage a vast array of conditions that impact oral and overall health. ${ }^{21}$ Already dentistry is seeing a change in the health care industry with the coverage of dental services for patients who have periodontal disease, are pregnant, or have cardiovascular disease or diabetes. ${ }^{22}$ Not only will dentists be expected to have exceptional technical skills, but they will also be required to possess exceptional diagnostic skills to be "capable of assessing and managing a multitude of oral pathologies and knowledgeable about sophisticated biomedical science concepts," as Hendricson and Cohen have said. ${ }^{23}$

Diabetes mellitus and tobacco use are known risk factors for periodontal disease..$^{19,24,25}$ The rate of diabetes is increasing in the U.S. population. Approximately 5 percent of all patients seen in dental offices are estimated to have diabetes, and the prevalence increases to 20-25 percent in patients sixty to seventy-four years of age. ${ }^{26,27}$ In one meta-analysis of eighteen comparative cross-sectional studies, subjects with diabetes had substantially more severe periodontal disease when compared to healthy subjects. ${ }^{25}$ In another meta-analysis of ten intervention studies, periodontal treatment resulted in a 0.66 percent reduction in absolute HbAlc levels among patients with type 2 diabetes. ${ }^{28}$

In 2001, Kornman suggested that diabetes greatly increases demands on the health care system. ${ }^{29} \mathrm{He}$ recommended that dental students be trained to manage the risk for periodontal disease among diabetic patients since this method can provide an effective and focused mechanism for learning about clinical management of diabetes. However, no reports could be identified in the literature regarding what dental students are taught about diabetes diagnosis and management.

Kunzel et al. investigated the role of the general dental practitioner in both smoking cessation activities and diabetes management. ${ }^{30}$ Their survey of 132 active general dentists found that a majority of the respondents do not incorporate smoking-cessation activities into their practices on a routine basis. In addition, while these general dentists inquire about a new patient's diabetic status, most do not behave proactively (monitoring blood glucose levels, communicating with the patient's physician, and adjusting the frequency of dental visits). The majority of the respondents reported having a lack of knowledge or viewing these activities as peripheral to their role. This 2005 report was the first to document the extent of dentists' practice activities regarding management of patients with diabetes.

The American Dental Education Association (ADEA) has established basic core competencies for dental education relevant to the issue of periodontal-systemic disease education. The ADEA Policy Statement on research states that "dental educators should be expected to include new information and research findings in their courses of instruction and to encourage students to engage in critical thinking and research." ${ }^{31}$ The Competencies for the New General Dentist approved by the ADEA House of Delegates in $2008^{32}$ also emphasizes the need for the general dentist to go beyond the traditional practice of focusing only on oral health and being able to practice evidence-based comprehensive dentistry both independently and collaboratively to improve the health of society. These goals will be accomplished by expanding the broad biomedical and clinical education of dentists. (See Figure 1.)

What is not known from the dental literature is what is actually being taught to dental students regarding periodontal disease and systemic conditions and how students are being prepared to manage patients with potential risk factors. We do not know if they are evaluated on their ability to identify potential risk factors or on their communication skills with patients and other health care providers about the patient's condition. We also do not know the topics or extent of information dental students receive regarding periodontal oral-systemic disease. To address this knowledge gap, our study was conducted to 1) determine what topics that address periodontal and systemic disease are included in the didactic and clinical curricula of dental schools; 2) evaluate the extent to which periodontal oral-systemic disease content is taught in an interdisciplinary format involving dental students and other health professions students; 3 ) ascertain the opinions of academic deans/dental administrators about the level of education their students receive pertaining to the relationship between periodontal and systemic disease; 4) elicit academic deans/dental administrators' opinions about the knowledge level of other health professions faculty in their institution and in the community concerning the relationship of oral health to systemic disease; and 5) identify resources needed to teach this content. For purposes of this article, the term "periodontal-systemic disease connection" will be used as it relates to the influence of periodontal conditions on systemic disease as well as the reverse scenario whereby systemic disease may influence the periodontal condition. 


\section{ADEA Policy Statements}

\section{Education: Curriculum Content}

All dental education institutions and programs should:

Develop and support new models of oral health care that involve other health professionals as team members in assessing the oral health status of patients and teach dental students to assume leadership roles in the detection, early recognition, and management of a broad range of complex oral and general diseases and conditions. When possible, interdisciplinary educational opportunities should be pursued.

...

Provide experiences working as a member of an interdisciplinary health care team.

...

\section{Research}

... Dental educators should be expected to include new information and research findings in their courses of instruction and to encourage students to engage in critical thinking and research. Students should be encouraged to contribute to the development of new knowledge for the profession.

..

\section{Health Promotion and Disease Prevention ...}

ADEA supports and encourages research into the correlation between oral and general health, including the possible link between periodontal disease and heart and lung diseases, stroke, diabetes, low birth rates, and premature births.

ADEA supports and encourages the education of students, professionals, and the public on behaviors that will prevent disease and promote health, including preventive oral health care measures, proper nutrition, and tobacco cessation.

Source: ADEA policy statements. J Dent Educ 2008;72(7):810-22.

\section{Competencies for the New General Dentist (As approved by the 2008 ADEA House of Delegates)}

The general dentist is the primary oral health care provider. . . . The general dentist will address health care issues beyond traditional oral health care and must be able to independently and collaboratively practice evidence-based comprehensive dentistry with the ultimate goal of improving the health of society. The general dentist must have a broad biomedical and clinical education and be able to demonstrate professional and ethical behavior as well as effective communication and interpersonal skills. In addition, he or she must have the ability to evaluate and utilize emerging technologies, continuing professional development opportunities, and problem-solving and critical thinking skills to effectively address current and future issues in health care.

$$
\cdots
$$

\section{Professionalism \\ Graduates must be competent to:}

...

2.2 Practice within one's scope of competence and consult with or refer to professional colleagues when indicated.

..

\section{Health Promotion Graduates must be competent to:}

...

4.2 Participate with dental team members and other health care professionals in the management and health promotion for all patients.

...

\section{Patient Care Graduates must be competent to: \\ ..}

6.5 Recognize the manifestations of systemic disease and how the disease and its management may affect the delivery of dental care.

6.6 Formulate a comprehensive diagnosis, treatment, and/or referral plan for the management of patients.

..

Source: American Dental Education Association. Competencies for the new general dentist. J Dent Educ 2008;72(7):823-6.

Figure 1. Examples from ADEA Policy Statements and Competencies for the New General Dentist that emphasize content/experiences in periodontal-systemic disease connections 


\section{Methods}

A thirty-four question survey was designed and organized into five sections: institutional demographics, topics included in the didactic curriculum, topics included in the clinical curriculum, opinions, and resource materials. The survey contained Likert-scale questions along with open-ended and closed-ended questions. The survey was developed with the assistance of experts in survey design as well as content experts on periodontal oral-systemic disease connections. Once designed, the survey instrument was approved by the University of North Carolina Institutional Review Board (IRB) and pilot-tested with the assistance of five dental school academic deans from different institutional settings. Minor corrections were made, and the survey was resubmitted to the IRB for final approval. The final survey was posted on Survey Monkey, an online survey website engine, which provided a URL for the survey.

School websites along with telephone calls were utilized to locate email addresses for the academic deans. The survey instrument URL and cover letter explaining the purpose of the survey were emailed to the academic deans of sixty-five accredited U.S. and Canadian dental schools in fall 2007. The letter requested that the survey be completed by the most appropriate person in the recipient's school. A second email with the URL to the survey was sent three weeks after the first mailing. Finally, a paper copy of the survey was mailed to all nonrespondents in an attempt to increase the response rate. The academic deans were informed that their participation was voluntary, with no incentives other than contributing to the dental literature.

The data were analyzed using descriptive statistical methods. The open-ended questions were separated into categories based on how the participants responded.

\section{Results}

A total of fifty schools responded to the online and paper surveys, achieving a response rate of 77 percent. Six of the respondents were from Canadian institutions. No differences were noted between the U.S. and Canadian responses. Forty-nine percent of the respondents were located in health science centers, and 47 percent were in universities with a medical school. All schools said they offer a D.D.S. or D.M.D. degree, 75 percent an M.S. or M.Sc., and 47 percent a Ph.D. Thirty-one percent of the schools reported employing between forty-one and sixty full-time faculty members, and 23 percent employ 100 or more. Seventy-one percent of the respondents identified themselves as being in the position of associate dean or dean, and 18 percent a program director or chair. Primary response patterns are discussed below. Not all questions were answered by every respondent.

\section{Topics Included in the Didactic Curriculum}

Respondents were asked to estimate the number of hours used to teach various topics typically included when considering the interaction between periodontal and systemic diseases. Topics listed were adverse pregnancy outcomes, aging, cardiovascular disease (CVD), diabetes, genetics of periodontal diseases in chronic periodontitis and aggressive periodontitis, genetics (periodontal diseases with genetic syndromes), HIV, obesity, osteoporosis, respiratory disease, stress, stroke, and tobacco use (Table 1). The topics said to be taught the most ( $\geq 6$ hours) are aging (56 percent), CVD (53 percent), diabetes (53 percent), tobacco use (52 percent), and HIV (48 percent). In the three-to-five-hour category, the topics receiving the most didactic time were said to be HIV (36 percent), genetics in chronic and aggressive periodontitis (34 percent), stress (33 percent), tobacco use (33 percent), and stroke ( 32 percent). Only 26 percent $(\mathrm{N}=11)$ of the respondents reported that their students receive three or more hours of instruction about adverse pregnancy outcomes as it relates to periodontal-systemic disease connections.

A list of nineteen courses was provided for respondents to select where in the curriculum content is taught regarding periodontal-systemic disease interactions/connections. The majority responded that they teach this content in periodontology (93 percent), followed by oral medicine ( 85 percent), general and oral pathology ( 80 percent), clinical periodontics (76 percent, first- or second-year didactic course), and clinical periodontics ( 74 percent, third- or fourth-year didactic course). One hundred percent reported they use lectures to teach the content. Case-based instruction is used by 70 percent, followed by seminars ( 47 percent) and problem-based learning (23 percent). All respondents said they use multiple-choice testing to evaluate knowledge of content, followed by case-based questions (68 percent). 
Table 1. Topics and hours included in the didactic curriculum regarding periodontal-systemic disease associations, by number and percentage of total respondents

Estimate how many didactic hours are used to teach concepts regarding periodontal-systemic disease associations for the following areas (check only one response).

\begin{tabular}{|c|c|c|c|c|c|c|c|}
\hline Answer Options & 0 & $>0$ and $<1$ & $1-2$ & $3-5$ & $6-8$ & $>8$ & Total \\
\hline $\begin{array}{l}\text { Adverse pregnancy outcomes } \\
\text { (low birthweight/preterm delivery) }\end{array}$ & $\overline{(0)}$ & $\begin{array}{l}37.2 \% \\
(16)\end{array}$ & $\begin{array}{c}37.2 \% \\
(16)\end{array}$ & $\begin{array}{l}18.6 \% \\
(8)\end{array}$ & $\overline{(0)}$ & $\begin{array}{l}7.0 \% \\
(3)\end{array}$ & 43 \\
\hline Aging & $\begin{array}{l}2.2 \% \\
(1)\end{array}$ & $\begin{array}{l}6.7 \% \\
(3)\end{array}$ & $\begin{array}{l}6.7 \% \\
(3)\end{array}$ & $\begin{array}{c}28.9 \% \\
(13)\end{array}$ & $\begin{array}{l}17.8 \% \\
(8)\end{array}$ & $\begin{array}{l}37.8 \% \\
(17)\end{array}$ & 45 \\
\hline Cardiovascular disease & $\overline{(0)}$ & $\begin{array}{l}4.4 \% \\
(2)\end{array}$ & $\begin{array}{l}15.6 \% \\
(7)\end{array}$ & $\begin{array}{l}26.7 \% \\
(12)\end{array}$ & $\begin{array}{l}17.8 \% \\
(8)\end{array}$ & $\begin{array}{l}35.6 \% \\
(16)\end{array}$ & 45 \\
\hline Diabetes & $\overline{(0)}$ & $\begin{array}{l}2.2 \% \\
(1)\end{array}$ & $\begin{array}{l}13.3 \% \\
(6)\end{array}$ & $\begin{array}{l}31.1 \% \\
(14)\end{array}$ & $\begin{array}{l}17.8 \% \\
(8)\end{array}$ & $\begin{array}{l}35.6 \% \\
(16)\end{array}$ & 45 \\
\hline $\begin{array}{l}\text { Genetics in chronic and aggressive } \\
\text { periodontitis }\end{array}$ & $\begin{array}{l}2.3 \% \\
(1)\end{array}$ & $\begin{array}{c}18.2 \% \\
(8)\end{array}$ & $\begin{array}{l}27.3 \% \\
(12)\end{array}$ & $\begin{array}{l}34.1 \% \\
(15)\end{array}$ & $\begin{array}{l}11.4 \% \\
(5)\end{array}$ & $\begin{array}{l}6.8 \% \\
(3)\end{array}$ & 44 \\
\hline $\begin{array}{l}\text { Genetics in periodontal diseases with } \\
\text { genetic syndromes }\end{array}$ & $\begin{array}{l}2.2 \% \\
(1)\end{array}$ & $\begin{array}{l}20.0 \% \\
(9)\end{array}$ & $\begin{array}{l}35.6 \% \\
(16)\end{array}$ & $\begin{array}{c}26.7 \% \\
(12)\end{array}$ & $\begin{array}{c}11.1 \% \\
(5)\end{array}$ & $\begin{array}{l}4.4 \% \\
(2)\end{array}$ & 45 \\
\hline HIV & $\overline{(0)}$ & $\begin{array}{l}9.1 \% \\
(4)\end{array}$ & $\begin{array}{c}6.8 \% \\
(3)\end{array}$ & $\begin{array}{c}36.4 \% \\
(16)\end{array}$ & $\begin{array}{c}29.5 \% \\
(13)\end{array}$ & $\begin{array}{c}18.2 \% \\
(8)\end{array}$ & 44 \\
\hline Obesity & $\begin{array}{c}4.4 \% \\
(2)\end{array}$ & $\begin{array}{c}37.8 \% \\
(17)\end{array}$ & $\begin{array}{c}22.2 \% \\
(10)\end{array}$ & $\begin{array}{c}22.2 \% \\
(10)\end{array}$ & $\begin{array}{l}6.7 \% \\
(3)\end{array}$ & $\begin{array}{l}6.7 \% \\
(3)\end{array}$ & 45 \\
\hline Osteoporosis & $\overline{(0)}$ & $\begin{array}{c}22.7 \% \\
(10)\end{array}$ & $\begin{array}{c}40.9 \% \\
(18)\end{array}$ & $\begin{array}{c}18.2 \% \\
(8)\end{array}$ & $\begin{array}{l}6.8 \% \\
(3)\end{array}$ & $\begin{array}{c}11.4 \% \\
(5)\end{array}$ & 44 \\
\hline Respiratory disease & $\overline{(0)}$ & $\begin{array}{l}20.9 \% \\
(9)\end{array}$ & $\begin{array}{c}27.9 \% \\
(12)\end{array}$ & $\begin{array}{c}23.3 \% \\
(10)\end{array}$ & $\begin{array}{c}14.0 \% \\
(6)\end{array}$ & $\begin{array}{c}14.0 \% \\
(6)\end{array}$ & 43 \\
\hline Stress & $\begin{array}{c}2.2 \% \\
(1)\end{array}$ & $\begin{array}{c}33.3 \% \\
(15)\end{array}$ & $\begin{array}{c}17.8 \% \\
(8)\end{array}$ & $\begin{array}{c}33.3 \% \\
(15)\end{array}$ & $\begin{array}{l}6.7 \% \\
(3)\end{array}$ & $\begin{array}{l}6.7 \% \\
(3)\end{array}$ & 45 \\
\hline Stroke & $\overline{(0)}$ & $\begin{array}{c}25.0 \% \\
(11)\end{array}$ & $\begin{array}{l}20.5 \% \\
(9)\end{array}$ & $\begin{array}{c}31.8 \% \\
(14)\end{array}$ & $\begin{array}{l}11.4 \% \\
(5)\end{array}$ & $\begin{array}{l}11.4 \% \\
(5)\end{array}$ & 44 \\
\hline Tobacco use & $\overline{(0)}$ & $\begin{array}{l}2.4 \% \\
(1)\end{array}$ & $\begin{array}{c}11.9 \% \\
(5)\end{array}$ & $\begin{array}{c}33.3 \% \\
(14)\end{array}$ & $\begin{array}{c}23.8 \% \\
(10)\end{array}$ & $\begin{array}{c}28.6 \% \\
(12)\end{array}$ & 42 \\
\hline Other (specify) & & & & & & & 4 \\
\hline Answered question & & & & & & & 45 \\
\hline Skipped question & & & & & & & 5 \\
\hline
\end{tabular}

Reference materials used to teach about periodontal-systemic disease connections are listed in Table 2. Ninety-three percent said they use journal articles, followed by dental textbooks (89 percent). Table 3 lists journals and other publications used to teach about this content. The top three journals that the respondents say they use are the Journal of Periodontology (87 percent), Journal of the American Dental Association (75 percent), and Oral Surgery, Oral Medicine, Oral Pathology, Oral Radiology, and Endodontology (55 percent). No respondents reported that their school uses corporate publications, and only 2 percent reported use of national health care agency publications. Other publications used by respondents that were named in the "other" category are the New England Journal of Medicine and Journal of the American Medical Association.
When asked which websites they use (if any) to communicate this content, respondents listed the American Academy of Periodontology (70 percent), Cochrane Library (44 percent), American Dental Association (37 percent), and National Institutes of Health (37 percent). No respondent indicated using corporate websites (Table 4).

Only 16 percent of the respondents $(\mathrm{N}=7)$ reported that they teach periodontal-systemic content to interdisciplinary student groups such as dental hygiene, nursing, medical, or other allied health students. The courses taught with dental students and other groups were reported as Periodontics I and II, Anesthesia, Introduction to Patient Care, Microbiology, Radiology, Infection and Immunity, Interprofessional Learning, Oral Medicine, Pharmacology, and General Pathology. The faculty who 


\section{Table 2. Resource materials used to teach about periodontal-systemic disease connections}

Resource Materials

Response Percentage

Response Number

Journal articles

Dental textbooks

$93.3 \%$

Internet sites or CDs from industry

$88.9 \%$

42

Other (specify)

Internet sites or CDs from national health care agencies

$31.1 \%$

40

Print materials from dental organizations (specify)

$26.7 \%$

12

$24.4 \%$

$24.4 \%$

$17.8 \%$

Medical/nursing textbooks

$8.9 \%$

Industry print materials (specify)

4

Answered question

Skipped question

\section{Table 3. Journals used to teach about periodontal-systemic disease connections}

Journal

Response Percentage

Response Number

Journal of Periodontology

Journal of the American Dental Association

$87.5 \%$

Oral Surgery, Oral Medicine, Oral Pathology, Oral Radiology, and Endodontology

$75.0 \%$

35

Journal of Clinical Periodontology

$55.0 \%$

30
22

Journal of Dental Research

$\begin{array}{ll}52.5 \% & 21\end{array}$

Journal of Periodontal Research

Grand Rounds in Oral-Systemic Medicine

$37.5 \%$

Journal of Evidence-Based Dental Practice

$35.0 \%$

15

Periodontology 2000

$32.5 \%$

14

Other (specify)

$30.0 \%$

$30.0 \%$

Journal of Dental Education

$22.5 \%$

$17.5 \%$

$15.0 \%$

Medical journal (specify)

Professional organization publications (specify)

$7.5 \%$

$5.0 \%$

$2.5 \%$

National health care agencies (specify)

Corporate publications (specify)

Answered question

-

Skipped question

\section{Table 4. Websites used to teach about periodontal-systemic disease connections}

Website Response Percentage

Response Number

American Academy of Periodontology

Cochrane Library

$\begin{array}{cc}70.4 \% & 19 \\ 44.4 \% & 12 \\ 37.0 \% & 10 \\ 37.0 \% & 10 \\ 11.1 \% & 3 \\ 7.4 \% & 2 \\ - & 0 \\ & 27 \\ & 23\end{array}$

teach the joint courses were identified by respondents as dental clinicians, basic scientists, and medical clinicians. One school reported that a dental hygiene faculty member teaches a course to interdisciplinary student groups. Only two respondents indicated they conduct joint projects or patient education in the area of periodontal-systemic connections in conjunction with other health professions students. One respon- 
dent noted that students complete the projects in a course called Population Health. Another indicated that rural rotations are multidisciplinary, and another wrote that the school is not yet doing joint projects but is working towards that goal.

Forty-eight percent of the respondents indicated that they provide formal training for their students in how to discuss or communicate aspects of periodontal-systemic disease connections with patients. Methods reported by respondents include observing the treatment planning process, discussing risk assessment with patients, patient care simulations, and role-playing; another provides the content as a component of a PBL curriculum. One respondent indicated the students at that dental school are evaluated on patient communication in all of the clinical competencies. One respondent indicated it is taught somewhat but not to achieve competence.

\section{Topics Included in the Clinical Curriculum}

Respondents also provided information on how dental students are evaluated in the clinic on their ability to assess for periodontal-systemic disease connections, discuss those risks with the patient, and refer the patient to a specialist based on risk factors (Table 5). Forty-four schools responded to this question and indicated that their students are evaluated for their ability to assess or perform a dental diagnosis or to discover a potential risk for systemic complications of periodontitis on the majority of their patients in relation to several health behaviors and medical conditions. Of the respondents, 67 percent reported that their students are evaluated on assessing risk for potential systemic disease with tobacco use, HIV (63 percent), CVD (62 percent), and diabetes (59 percent). Adverse pregnancy outcomes (51 percent)

Table 5. Evaluation of D.D.S. students on ability to assess, discuss risks, and refer patients who present with oral disease and systemic complications or risk factors for disease, by number and percentage of total respondents

In your clinical curriculum, are students evaluated on their ability to 1) assess for potential risks of "oral-systemic" complications; 2) discuss risks with the patient; 3) refer the patient to a dental or medical specialist based on the patient's risk factor(s) for oral disease and systemic complications? (Place a mark in the appropriate box if they perform the above on the majority of their patients.)

\begin{tabular}{|c|c|c|c|c|c|}
\hline & Assess & Discuss Risks & $\begin{array}{l}\text { Refer to a Dental or } \\
\text { Medical Specialist }\end{array}$ & Don't Know & $\begin{array}{l}\text { Response } \\
\text { Count }\end{array}$ \\
\hline $\begin{array}{l}\text { Adverse pregnancy outcomes } \\
\text { (low birthweight/preterm delivery) }\end{array}$ & $\begin{array}{l}51.2 \% \\
(21)\end{array}$ & $\begin{array}{c}53.7 \% \\
(22)\end{array}$ & $\begin{array}{l}26.8 \% \\
(11)\end{array}$ & $\begin{array}{c}24.4 \% \\
(10)\end{array}$ & 41 \\
\hline Aging & $\begin{array}{c}56.4 \% \\
(22)\end{array}$ & $\begin{array}{l}66.7 \% \\
(26)\end{array}$ & $\begin{array}{l}33.3 \% \\
(13)\end{array}$ & $\begin{array}{l}12.8 \% \\
(5)\end{array}$ & 39 \\
\hline Cardiovascular disease & $\begin{array}{l}61.9 \% \\
(26)\end{array}$ & $\begin{array}{l}71.4 \% \\
(30)\end{array}$ & $\begin{array}{l}64.3 \% \\
(27)\end{array}$ & $\begin{array}{l}2.4 \% \\
(1)\end{array}$ & 42 \\
\hline Diabetes & $\begin{array}{l}59.1 \% \\
(26)\end{array}$ & $\begin{array}{l}77.3 \% \\
(34)\end{array}$ & $\begin{array}{l}61.4 \% \\
(27)\end{array}$ & $\overline{(0)}$ & 44 \\
\hline Genetics & $\begin{array}{l}43.2 \% \\
(16)\end{array}$ & $\begin{array}{l}45.9 \% \\
(17)\end{array}$ & $\begin{array}{l}40.5 \% \\
(15)\end{array}$ & $\begin{array}{l}16.2 \% \\
(6)\end{array}$ & 37 \\
\hline HIV & $\begin{array}{l}62.8 \% \\
(27)\end{array}$ & $\begin{array}{c}69.8 \% \\
(30)\end{array}$ & $\begin{array}{c}53.5 \% \\
(23)\end{array}$ & $\begin{array}{l}4.7 \% \\
(2)\end{array}$ & 43 \\
\hline Obesity & $\begin{array}{l}55.3 \% \\
(21)\end{array}$ & $\begin{array}{c}42.1 \% \\
(16)\end{array}$ & $\begin{array}{l}26.3 \% \\
(10)\end{array}$ & $\begin{array}{l}18.4 \% \\
(7)\end{array}$ & 38 \\
\hline Osteoporosis & $\begin{array}{c}52.4 \% \\
(22)\end{array}$ & $\begin{array}{c}54.8 \% \\
(23)\end{array}$ & $\begin{array}{c}40.5 \% \\
(17)\end{array}$ & $\begin{array}{l}9.5 \% \\
(4)\end{array}$ & 42 \\
\hline Respiratory disease & $\begin{array}{l}52.5 \% \\
(21)\end{array}$ & $\begin{array}{c}52.5 \% \\
(21)\end{array}$ & $\begin{array}{c}37.5 \% \\
(15)\end{array}$ & $\begin{array}{c}15.0 \% \\
(6)\end{array}$ & 40 \\
\hline Stress & $\begin{array}{c}52.5 \% \\
(21)\end{array}$ & $\begin{array}{c}55.0 \% \\
(22)\end{array}$ & $\begin{array}{c}35.0 \% \\
(14)\end{array}$ & $\begin{array}{c}15.0 \% \\
(6)\end{array}$ & 40 \\
\hline Stroke & $\begin{array}{c}58.5 \% \\
(24)\end{array}$ & $\begin{array}{c}56.1 \% \\
(23)\end{array}$ & $\begin{array}{c}48.8 \% \\
(20)\end{array}$ & $\begin{array}{c}9.8 \% \\
(4)\end{array}$ & 41 \\
\hline Tobacco use & $\begin{array}{c}66.7 \% \\
(28)\end{array}$ & $\begin{array}{c}85.7 \% \\
(36)\end{array}$ & $\begin{array}{c}50.0 \% \\
(21)\end{array}$ & $\overline{(0)}$ & 42 \\
\hline Answered question & & & & & 44 \\
\hline Skipped question & & & & & 6 \\
\hline
\end{tabular}

The original version of this article contained an error in Table 5. A correction notice was published in May 2009, and this updated version of the article PDF reflects the corrected table data. 
and genetics (43 percent) were said to be less frequently assessed. Likewise, the students' ability to discuss risks with patients was said to be evaluated mostly with tobacco use ( 86 percent), diabetes (77 percent), CVD (71 percent), and HIV (70 percent). Participants were asked if their students are evaluated on their ability to refer the patient to a specialist based on the patient's risk factor(s) for periodontal oral-systemic disease connections. According to the respondents, fewer programs evaluate students on referral ability, but when they are evaluated, the most frequently reported conditions for referral are CVD
(64 percent), diabetes (61 percent), HIV (53 percent), and tobacco use (50 percent). Ten schools reported that they did not know if and how risk assessment and medical referrals for adverse pregnancy outcomes are evaluated in their curricula.

\section{Opinions}

One section of the survey focused on opinions of the respondents regarding periodontal-systemic education, resource materials, and levels of expertise in their programs and community (Table 6). The

Table 6. Opinions of academic deans/administrators/faculty members on the individual parameters regarding oral-systemic disease at their institution, by number and percentage of total respondents

\begin{tabular}{|c|c|c|c|c|c|c|}
\hline & $\begin{array}{l}\text { Strongly } \\
\text { Agree }\end{array}$ & Agree & Disagree & $\begin{array}{l}\text { Strongly } \\
\text { Disagree }\end{array}$ & $\begin{array}{l}\text { Don't } \\
\text { Know }\end{array}$ & Total \\
\hline $\begin{array}{l}\text { 1. The clinical faculty in our school are knowledgeable } \\
\text { about oral-systemic research. }\end{array}$ & $\begin{array}{l}14.0 \% \\
(6)\end{array}$ & $\begin{array}{l}55.8 \% \\
\quad(24)\end{array}$ & $\begin{array}{l}25.6 \% \\
(11)\end{array}$ & $\overline{(0)}$ & $\begin{array}{l}4.7 \% \\
(2)\end{array}$ & 43 \\
\hline $\begin{array}{l}\text { 2. The faculty who teach about the oral-systemic } \\
\text { associations know how to critically evaluate the } \\
\text { literature and determine levels of evidence for } \\
\text { associations between them. }\end{array}$ & $\begin{array}{l}51.2 \% \\
(22)\end{array}$ & $\begin{array}{l}46.5 \% \\
(20)\end{array}$ & $\begin{array}{l}2.3 \% \\
(1)\end{array}$ & $\overline{(0)}$ & $\overline{(0)}$ & 43 \\
\hline $\begin{array}{l}\text { 3. We need more experts at our school who can teach } \\
\text { this subject to our dental students. }\end{array}$ & $\begin{array}{l}7.0 \% \\
(3)\end{array}$ & $\begin{array}{l}51.2 \% \\
(22)\end{array}$ & $\begin{array}{l}32.6 \% \\
(14)\end{array}$ & $\begin{array}{l}9.3 \% \\
(4)\end{array}$ & $\overline{(0)}$ & 43 \\
\hline $\begin{array}{l}\text { 4. Dental students should be able to assess a patient's } \\
\text { periodontal condition and appropriately advise them } \\
\text { about possible systemic complications. }\end{array}$ & $\begin{array}{l}55.8 \% \\
(24)\end{array}$ & $\begin{array}{l}41.9 \% \\
(18)\end{array}$ & $\overline{(0)}$ & $\begin{array}{l}2.3 \% \\
(1)\end{array}$ & $\overline{(0)}$ & 43 \\
\hline $\begin{array}{l}\text { 5. Dentists will play an important role in the future in } \\
\text { assessing patients' risk for systemic complications due } \\
\text { to oral health status. }\end{array}$ & $\begin{array}{l}55.8 \%) \\
\quad(24\end{array}$ & $\begin{array}{l}37.2 \% \\
(16)\end{array}$ & $\begin{array}{l}7.0 \% \\
(3)\end{array}$ & $\overline{(0)}$ & $\overline{(0)}$ & 43 \\
\hline $\begin{array}{l}\text { 6. Our dental students are knowledgeable about the role } \\
\text { of inflammation and its impact on oral-systemic } \\
\text { complications. }\end{array}$ & $\begin{array}{c}32.6 \% \\
(14)\end{array}$ & $\begin{array}{c}55.8 \% \\
(24)\end{array}$ & $\begin{array}{c}11.6 \% \\
(5)\end{array}$ & $\overline{(0)}$ & $\overline{(0)}$ & 43 \\
\hline $\begin{array}{l}\text { 7. Our school does an excellent job of didactically } \\
\text { teaching dental students regarding the oral-systemic } \\
\text { connection. }\end{array}$ & $\begin{array}{c}25.6 \% \\
(11)\end{array}$ & $\begin{array}{c}55.8 \% \\
(24)\end{array}$ & $\begin{array}{c}14.0 \% \\
(6)\end{array}$ & $\overline{(0)}$ & $\begin{array}{c}4.7 \% \\
(2)\end{array}$ & 43 \\
\hline $\begin{array}{l}\text { 8. Our school does an excellent job of evaluating dental } \\
\text { students' knowledge regarding the oral-systemic } \\
\text { connection in the clinical setting. }\end{array}$ & $\begin{array}{c}25.6 \%) \\
(11\end{array}$ & $\begin{array}{c}25.6 \% \\
(11)\end{array}$ & $\begin{array}{c}37.2 \% \\
(16)\end{array}$ & $\begin{array}{c}4.7 \% \\
(2)\end{array}$ & $\begin{array}{c}7.0 \% \\
(3)\end{array}$ & 43 \\
\hline $\begin{array}{l}\text { 9. Our school could use more evidence-based educational } \\
\text { materials (slides, pamphlets, etc.) to help teach these } \\
\text { concepts to dental students. }\end{array}$ & $\begin{array}{c}14.0 \% \\
(6)\end{array}$ & $\begin{array}{c}72.1 \% \\
(31)\end{array}$ & $\begin{array}{c}11.6 \% \\
(5)\end{array}$ & $\begin{array}{c}2.3 \% \\
(1)\end{array}$ & $\overline{(0)}$ & 43 \\
\hline $\begin{array}{l}\text { 10. Nurses and physicians in our geographic location } \\
\text { (city, state, region) are well educated about oral-systemic } \\
\text { associations. }\end{array}$ & $\begin{array}{l}2.4 \% \\
(1)\end{array}$ & $\begin{array}{c}7.1 \% \\
(3)\end{array}$ & $\begin{array}{c}50.0 \% \\
(21)\end{array}$ & $\begin{array}{c}26.2 \% \\
(11)\end{array}$ & $\begin{array}{c}14.3 \% \\
(6)\end{array}$ & 42 \\
\hline $\begin{array}{l}\text { 12. In general, nurses and physicians are knowledgeable } \\
\text { about oral health and its relationship to systemic disease. }\end{array}$ & $\begin{array}{l}2.3 \% \\
(1)\end{array}$ & $\begin{array}{l}11.6 \% \\
(5)\end{array}$ & $\begin{array}{l}60.5 \% \\
(26)\end{array}$ & $\begin{array}{l}18.6 \% \\
(8)\end{array}$ & $\begin{array}{l}7.0 \% \\
(3)\end{array}$ & 43 \\
\hline $\begin{array}{l}\text { 13. Our school needs to provide more content to dental } \\
\text { students on the relationship between oral disease and } \\
\text { systemic health. }\end{array}$ & $\begin{array}{l}7.0 \% \\
(3)\end{array}$ & $\begin{array}{l}46.5 \% \\
(20)\end{array}$ & $\begin{array}{l}39.5 \% \\
(17)\end{array}$ & $\overline{(0)}$ & $\begin{array}{l}7.0 \% \\
(3)\end{array}$ & 43 \\
\hline $\begin{array}{l}\text { 14. Our dental students are knowledgeable about how to } \\
\text { work in interdisciplinary teams to promote oral-systemic } \\
\text { health. }\end{array}$ & $\begin{array}{l}4.9 \% \\
(2)\end{array}$ & $\begin{array}{l}48.8 \% \\
(20)\end{array}$ & $\begin{array}{c}31.7 \% \\
(13)\end{array}$ & $\begin{array}{c}7.3 \% \\
(3)\end{array}$ & $\begin{array}{c}7.3 \% \\
(3)\end{array}$ & 41 \\
\hline Answered question & & & & & & 43 \\
\hline Skipped question & & & & & & 7 \\
\hline
\end{tabular}


respondents said they feel confident in their clinical faculty members' knowledge level regarding oralsystemic content (70 percent strongly agreed [SA] or agreed [A]) and also in their ability to evaluate critically the literature and determine levels of evidence (97 percent SA or A). However, 58 percent strongly agreed or agreed that they need more experts at their dental school to teach such content. Most respondents (89 percent SA or A) judged their dental students as knowledgeable about the role of inflammation and its impact on periodontal-systemic conditions. Regarding the role of future dentists in assessing patients' risk for systemic complications due to oral health status, 93 percent rated the dentists' role as important. Eighty-two percent reported that their school is doing an excellent job of didactically teaching dental students regarding periodontal oral-systemic disease connections; however, only 51 percent perceive that their school is doing an excellent job with evaluation of the content in the clinical setting. Regarding the knowledge level of medical colleagues (physicians and nurses) about periodontal-systemic disease connections, most respondents disagreed or strongly disagreed that the professionals in their geographic location, health science center, or in general are knowledgeable about this area of care (76 percent, 63 percent, and 79 percent, respectively). Finally, the majority of the respondents ( 86 percent) reported they could use more evidence-based educational materials to teach dental students about periodontal-systemic disease connections.

\section{Resources}

The respondents were asked if their program supplies resource materials on periodontal-systemic disease associations such as patient literature or medical referral letters and templates. Fifty-one percent said their program supplies resource materials, and 67 percent said they provide referral letters to patients. The final question asked if there was anything the respondents would like to have that would assist them in teaching this content to dental students. Resources identified include patient pamphlets in both English and Spanish; instructional modules; access to a speaker's bureau with individuals who can teach this content and be "trusted"; and an outside consultant to work with the clinical faculty, curriculum committee, or academic dean to develop and implement a plan for revision of this part of the curriculum.

The final question asked participants for comments about the survey or if their school had future plans for curriculum content related to periodontalsystemic disease research. The answers varied regarding the level of emphasis on this area in the dental curriculum from a full curriculum revision to very little change and integration (Figure 2).

\section{Discussion}

Since 1995, several national reports have focused on the importance of oral health to systemic conditions and the need for more integration of dentistry with medicine and the health care system as a whole..$^{33-36}$ The Institute of Medicine report (IOM) published in 1995 recommended that dentists be prepared for more medically based modes of oral health care and be prepared to work with more medically compromised patients along with their colleagues in medical schools and academic health centers. ${ }^{35}$ The surgeon general's report on oral health focused national attention on the importance of oral health..$^{33}$ It discussed the emerging associations between oral health and systemic conditions and emphasized the impact of systemic health problems on poor oral health. Specifically, the report discussed emerging associations of chronic oral infections such as periodontal disease to diabetes, heart and lung diseases, stroke, adverse pregnancy outcomes, and other conditions. However, although much attention has been paid to this important area in the literature, our study reported in this article is the first documenting the periodontal-systemic disease content taught to U.S. and Canadian dental students.

Overall, we found that academic deans and administrators are confident in their faculties' ability to teach dental students about periodontal-systemic disease connections. Ninety-eight percent reported that the faculty members who teach these concepts effectively and critically evaluate evidence on these associations. While the literature is not conclusive regarding any etiologic role for oral/periodontal disease on systemic conditions, it is important for faculty members to teach students how to read the literature and stay abreast of current findings in this area. Considering predictions that dentists and other oral health care providers will play an important role in overall health care, ${ }^{33-36}$ it is vital that dental students begin that preparation while in the academic setting.

All of the respondents to our survey reported that lecture methods are used to teach this content, followed by case-based instruction (used by 70 per- 
"We will be revising our curriculum to emphasize the oral-systemic connection and are in the process of establishing a center specifically to focus on this area of research."

"Although I am confident about our students' knowledge (didactic), I am not confident about practical application."

"Our school is reviewing and planning a major curriculum revision in which oral-systemic content will be central."

"Periodontics and oral medicine interact very closely and very well at our college. Our approach to teaching is similar. Overall, the hyperbole should be limited and emphasis placed on solid causation data from randomized prospective studies. 'Floss or Die' type approaches are unfounded. We have tried to expose our students to solid data."

"We are working on inflammation as a research initiative which may bring more students in contact with literature on this subject. A curriculum review currently under way may lead to better integration of content across disciplines."

"The link between oral and systemic disease is only a theory and has not been proven. The connections are purely statistical. There may be no clinical relevance to this at all. We introduce this topic to students, but we do not believe it is a critical component to our teaching efforts."

"The curriculum adapts to changing or new diseases_ever evolving."

Figure 2. Selected comments from respondents regarding the survey and their future plans for periodontal-systemic content at their institution

cent). Seminars and problem-based learning were said to be used by less than half of the schools to teach about periodontal oral-systemic conditions. This is not surprising given the overcrowded curriculum in the majority of dental schools. Yet, reports indicate that the process of teaching students to practice according to evidence does not happen with lecture methods alone. Hendricson et al. ${ }^{37}$ drawing on work by Werb and Matear, ${ }^{38}$ Bertolami, ${ }^{39}$ and Haden et al., ${ }^{40}$ described evidence-based practice (EBP) as "educating dental students to provide patient care that is supported by research evidence versus the historical 'in my experience' approach and to instill an educational culture that values and promotes intellectual curiosity, based on the intertwined mental capacities of critical appraisal, self-directed learning, self-assessment, and reflection upon actions, decisions, and behaviors." Coormarasamy and Khan conducted a systematic review of published research regarding educational strategies to help medical students and residents acquire skills associated with EBP. ${ }^{41}$ Specifically, they looked at the effect of "stand-alone" teaching strate- gies such as classroom-based teaching versus clinically integrated teaching such as literature searching assignments, case simulations, and case conferences. The authors concluded that the clinically integrated methods all reported substantial enhancements in critical appraisal skills and improvement in student attitudes and confidence in applying EBP methods to patient care. The classroom-restricted methods, on the other hand, produced only weak and inconsistent evidence for these changes in the students.

Since dental students will not have ready access to faculty members or senior mentors after they graduate, it is imperative that they learn critical appraisal and critical thinking skills while in the academic institution so they can implement EBP throughout their careers. Haden et al. reported that traditional pedagogy in dental education focuses on how well the student can memorize facts. ${ }^{40}$ But is it possible for students to learn or comprehend all of the information they need to become competent dentists? According to Haden et al., "Students must learn how to learn, and faculty must serve as role models who 
understand and value scientific discovery." ${ }^{40}$ In addition, as dental schools look to the curriculum they will need in the future, perhaps the sorts of redesign of biomedical science instruction proposed by Geissberger et al. should be considered. ${ }^{42}$ Freeing time in the dental curriculum for development of critical thinking, problem-solving, and lifelong learning skills may contribute to producing the well-prepared dentist of the future.

The abilities to problem-solve and think critically coincide with the ability to access evidencebased information. Respondents in our study reported that their institutions use journal articles and dental textbooks as the primary resource materials to teach content on periodontal-systemic disease connections. Of the journals used, the most frequently named were peer-reviewed publications such as the Journal of Periodontology (87.5 percent) and Journal of the American Dental Association (75 percent). Also mentioned was the use of websites such as those of the American Academy of Periodontology (77 percent) and the Cochrane Library (44 percent). These findings are consistent with a recent study of periodontal-systemic disease education in U.S. dental hygiene programs that found them utilizing journal articles and dental hygiene textbooks ( 90 percent and 87 percent, respectively) and peer-reviewed journals such as the Journal of Periodontology (84 percent) to teach this content. ${ }^{43}$ Academic institutions should incorporate evidence-based readings and websites into their dental curricula to ensure that students will be prepared to continue these practices after graduation.

Even though the respondents to our survey reported that the clinical faculty members at their institutions are knowledgeable about periodontalsystemic research, over one-third said they do not think their institution is doing an excellent job of evaluating dental students' knowledge of this content in the clinical setting. Many dental school faculty members do not have education or training in pedagogy or effective teaching strategies. Faculty development programs can be used to enhance their skills and encourage them to develop clinically integrated learning activities as well as critical thinking and problem-solving skills in students. As reported by Hendricson et al., the following characteristics produce the highest level of satisfaction in faculty development programs: incorporation of experiential learning such as hands-on practice of teaching skills; provision of feedback to participants about their performance; opportunities for participants to apply skills within the program or soon after; use of peers to model exemplary teaching behaviors and share perspectives on teaching; programs designed to facilitate peer interaction and the building of colleague relationships; use of a variety of learning experiences; and opportunities for post-program assessment of skills. ${ }^{37}$

According to the results of our survey, the topics that receive the most didactic hours on periodontal oral-systemic disease content in dental curricula are aging, CVD, diabetes, and tobacco use. A recent study of dental hygiene programs found that the most didactic hours are also allotted to diabetes, tobacco use, and CVD. ${ }^{43}$ The incidence of diabetes is expected to increase in the future and already impacts the majority of dental practices. ${ }^{44}$ Tobacco use is a high-risk factor for periodontal disease and oral cancer and should be emphasized in dental curricula as a periodontal systemic risk. ${ }^{19,45}$

Academic deans/administrators responding to our survey reported varying levels of clinical evaluation regarding dental students' ability to access periodontal systemic risks/complications and communicate with patients concerning these issues. When one looks at how the risk factors that receive the most didactic hours in dental curricula (Table 1) are translated into the clinical setting, there is much variation. For example, 67 percent of respondents said their schools evaluate students' ability to assess tobacco use, and 86 percent evaluate students' ability to discuss risks, yet only half evaluate students' decision making process in referring patients to a specialist for treatment. The survey did not ask about tobacco cessation activities provided by the dental schools, but the literature has reported a lack of tobacco cessation efforts by dentists and other health professionals. $^{46,47}$

Likewise, according to our survey, diabetes assessment is evaluated by 59 percent of programs, yet respondents said that students are evaluated on their ability to discuss the condition with the patient in 77 percent of the programs. The ability to refer to a specialist was said to be evaluated the most for CVD and diabetes. This finding is consistent with findings for U.S. dental hygiene programs. ${ }^{43}$ It is encouraging that the majority of dental and dental hygiene programs evaluate students' ability to perform these skills.

Surprisingly, dental students' ability to assess for genetic factors was said to be evaluated the least of all listed factors. Their ability to discuss risks with their patients was also near the bottom in re- 
sponses to our survey, when compared to other risk factors. The recent Macy Study report on genetics and dentistry emphasizes the need for dentists to be able to discuss genetic factors and genetic tests with patients. ${ }^{48}$ In addition, that report stresses the need for oral health professionals to be prepared to answer patients' questions and know where to refer them for additional information or counseling.

A significant finding of our study is the very limited amount of interprofessional education and collaboration in U.S. and Canadian dental schools. Our study found that only seven schools (16 percent) present periodontal oral-systemic content to interdisciplinary student groups including groups such as nursing, dental hygiene, or medical students. In addition, only two schools reported conducting joint projects or patient education with interprofessional students in the area of periodontal-systemic connections. Only 8 percent of schools said they were not affiliated with an academic health science center or other university structure that did not include a medical school; hence, the opportunity for some level of collaboration exists at most institutions. It was interesting that over half of the academic deans/ administrators reported that their dental students are knowledgeable about how to work in interdisciplinary teams to promote oral-systemic health, yet this survey found that most receive no formal experience in interdisciplinary learning. Hendricson and Cohen wrote that, in the twenty-first century, "The dental profession will have to decide whether it wants to become a more integrated competent of the overall health care system versus continuing the 'splendid isolation' tradition of dental practitioners functioning in relative isolation from physicians and other health care providers." ${ }^{23}$ The recent Macy Study report on clinical training in oral health emphasizes the overlap between the clinical dentistry knowledge needed by physicians and the clinical medicine knowledge needed by dentists to provide better health care to patients. ${ }^{49}$ Dentistry is at a crossroads, with dentists having an opportunity to provide collaborative care.

Other health professionals are beginning to realize the importance of oral health to overall health. A recent issue of the American Journal of Child and Maternal Nursing is entirely devoted to oral health, with one article entitled "Improving Oral Health in Women: Nurses' Call to Action." "50 The article provides a nurses' plan of action to emphasize the management of oral health conditions that are said to be "largely preventable." Finally, the article notes that nurses are in an ideal position to provide health promotion education and screening regarding oral health and risk factors for oral disease across the multitude of settings in which they work. Yet, nurses do not report a high level of knowledge regarding oral health and periodontal disease risks. A University of North Carolina study found that, of 240 North Carolina nurse practitioners, physician assistants, and certified nurse midwives, 62 percent reported having received no information in their educational curricula about oral health and periodontal disease. More than half were interested in attending continuing education courses to learn more about oral health. ${ }^{51}$ At the University of Washington, Mouradian et al. have recently reported on an oral health curriculum in the university's medical school. ${ }^{52}$ The findings of this survey indicate that, for the most part, dentistry continues to educate students in isolation from other health care professionals. Most predictions indicate that this philosophy will not be conducive to meeting the public's oral health care needs and expectations of the future. ${ }^{49-53}$

In our survey, only 9 percent of academic deans/administrators agreed or strongly agreed that nurses and physicians in their geographic location are well educated about periodontal-systemic disease connections. However, the percentage increased to 23 percent when respondents were asked about their particular health science center or academic campus. Thomas et al. found that nurse practitioners and certified nurse midwives were more likely to provide oral health exams if they had graduated from a school in close proximity to a dental school..$^{51}$ Perhaps being near a dental school increases the knowledge or conscientiousness level about oral health. In our study, 14 percent of the respondents answered that they did not know about the knowledge of nurses and physicians in their geographic location or academic institutions. A 2007 study reported the results of an investigation of knowledge level and behaviors of obstetricians and gynecologists regarding periodontal disease and adverse pregnancy outcomes. ${ }^{54} \mathrm{~A}$ high number of obstetricians correctly associated periodontal disease with bacteria, but believed periodontal disease to be associated with tooth decay, aging, and excess sugar. The study also found limited incorporation of oral health knowledge into clinical practice.

The exact nature of the effect of periodontal disease on adverse pregnancy outcomes has not yet been confirmed. ${ }^{7,20}$ However, it is clear that, at the very least, good periodontal health is important to the well-being and comfort of the pregnant patient. Some critics contend that the level of evidence of 
a periodontal-systemic disease connection varies with the condition and ask, since a cause-effect relationship has not been established, why would it be important to incorporate this information into the academic setting or devote precious curriculum time to a discussion of possible effects? While the level of evidence varies according to the condition, the promotion of good oral health in itself is important to the reduction of disease, infection, and unnecessary suffering. A reduction in the detrimental effects of periodontal and oral disease is best accomplished through collaboration between dental and other health care professionals and is best reinforced while students are in the academic setting.

Dental schools can develop alliances with other members of the health care team to promote better periodontal health and teach other professionals about risks for periodontal oral-systemic disease. The Macy Study panel 2 report provides suggestions for promoting interprofessional collaboration in medicine and dentistry. ${ }^{49}$ Sharing basic science courses is not enough, the authors of the report argue. Suggestions start with pairing medical and dental students at service-learning sites. Medical students could rotate through dental schools or community health centers and engage in joint learning experiences in cross-cutting competencies such as oral heath interviewing and examination skills. Dental students could also serve as mentors to medical students regarding oral health skills and vice versa for selected medical/diagnostic skills. As noted in the report of panel 1 of the Macy Study, ${ }^{55}$ multidisciplinary education must become the norm in addressing the meaning and purposes of primary care as it applies to dentistry. The authors of that report recommend educational sequences including rotation strategies across discipline specialties in medicine and dentistry, clerkships and hospital rotations, and experience in faculty and residency clinics. As an example, they recommend a dental presence in medical rotations to specialty clinics in endocrinology or dermatology or in special facilities for geriatric patients.

New York University (NYU) began an innovative collaboration when the NYU College of Nursing merged with the College of Dentistry. ${ }^{56}$ The College of Nursing faculty practice, located at the College of Dentistry, has the opportunity to see more than 300,000 patients per year, many of whom would not get needed medical care otherwise. In addition, the nurse practitioners work collaboratively with the dental students to provide ongoing primary care and other health promotion/disease prevention services and to refer patients as needed. This is just one example of how interprofessional collaborations can help ease the access to care crisis, while promoting better periodontal health and potentially lowering the risk for systemic conditions.

With curriculum change and innovation, dentistry can be at the forefront of meeting the oral health care needs of the future. Collaborative practice models must be developed and implemented in order to meet the oral health needs of the public and reduce the incidence of systemic manifestations of oral disease. Future research should focus on methods of integrating periodontal oral-systemic research into the classroom and clinical settings to promote critical thinking skills and EBP. In addition, strategies should be implemented to increase the level of interprofessional education in oral-systemic risk factors, prevention, and patient management across disciplines.

\section{Conclusions}

The findings from this survey suggest that academic deans of North American dental schools are confident about the knowledge level of their students regarding periodontal-systemic disease connections. However, more than half of the respondents indicated they need to provide more educational experiences in this area. Only a few dental schools implement courses on this topic in which dental students participate in interprofessional learning experiences with other health care students. In addition, most academic deans/administrators do not think that nurses and physicians are knowledgeable about oral health and its relationship to systemic disease. More research needs to be conducted to identify strategies that will assist the efforts of faculty to translate this area of science into dental curricula. In addition, curricular revisions need to occur to plan for increased interprofessional collaboration.

\section{Acknowledgments}

This study was supported by an unrestricted grant from Colgate Oral Pharmaceuticals. Colgate provided input into the initial review of the questionnaire only.

\section{REFERENCES}

1. Hunter W. An address on the role of sepsis and antisepsis in medicine. Lancet 1911:1-79.

2. Mattila KJ, Nieminen MS, Valtonen VV, Rasi VP, Kesäniemi YA, Syrjälä S, et al. Association between 
dental health and acute myocardial infarction. Br Med J 1989;298(6676):779-81.

3. Grossi SG, Skrepcinski FB, DeCaro T, Robertson DC, Ho AW, Dunford RG, et al. Treatment of periodontal disease in diabetics reduces glycated hemoglobin. J Periodontol 1997;68(8):713-9.

4. Grossi SG, Genco RJ. Periodontal disease and diabetes mellitus: a two-way relationship. Ann Periodontol 1998;3:51-61.

5. Taylor GW. Bidirectional interrelationships between diabetes and periodontal diseases: an epidemiologic perspective. Ann Periodontol 2001;6:99-112.

6. Scannapieco FA, Ho AW. Potential associations between chronic respiratory disease and periodontal disease: analysis of National Health and Nutrition Examination Survey III. J Periodontol 2001;72:50-6.

7. Offenbacher S, Katz V, Fertik G, Collins J, Boyd D, Maynor $\mathrm{G}$, et al. Periodontal infection as a possible risk factor for preterm low birth weight. J Periodontol 1996;67(10 Suppl):1103-13.

8. Jeffcoat MK, Geurs NC, Reddy MS, Cliver SP, Goldenberg RL, Hauth JC. Periodontal infection and preterm birth: results of a prospective study. J Am Dent Assoc 2001;132:875-80.

9. Desvarieux M, Demmer RT, Rundek T, Boden-Albala B, Jacobs DR Jr, Sacco RL, et al. Periodontal microbiota and carotid intima-media thickness: the oral infections and vascular disease epidemiology study (INVEST). Circulation 2005;111(5):576-82.

10. Tiong AY, Brieger D. Inflammation and coronary artery disease. Am Heart J 2005;150:11-8.

11. Bahekar AA, Singh S, Saha S, Molnar J, Arora R. The prevalence and incidence of coronary heart disease is significantly increased in periodontitis: a meta-analysis. Am Heart J 2007;154:830-7.

12. Wu T, Trevisan M, Genco RJ, Dorn JP, Falkner KL, Sempos CT. Periodontal disease and risk of cerebrovascular disease: the first National Health and Nutrition Examination Survey and its follow-up study. Arch Intern Med 2000;160(18):2749-55.

13. Joshipura KJ, Hung HC, Rimm EB, Willett WC, Ascherio A. Periodontal disease, tooth loss, and incidence of ischemic stroke. Stroke 2003;34(1):47-52.

14. Shultis WA, Weil EJ, Looker HC, Curtis JM, Shlossman M, Genco RJ, et al. Effect of periodontitis on overt nephropathy and end-stage renal disease in type 2 diabetes. Diabetes Care 2007;30(2):306-11.

15. Reeves AF, Rees JM, Schiff M, Hujoel P. Total body weight and waist circumference associated with chronic periodontitis among adolescents in the United States. Arch Pediatr Adolesc Med 2006;160:894-9.

16. Kaye EK. Bone health and oral health. J Am Dent Assoc 2007;138(5):616-9.

17. Borges I Jr, Moreira EA, Filho DW, de Oliveira TB, da Silva MB, Fröde TS. Proinflammatory and oxidative stress markers in patients with periodontal disease. Mediators Inflamm 2007;45:794.

18. Tomar SL, Asma S. Smoking-attributable periodontitis in the United States: findings from NHANES III (National Health and Nutrition Examination Survey). J Periodontol 2000;71(5):743-51.
19. Winn DM. Tobacco use and oral disease. J Dent Educ 2001;65(4):306-12.

20. Michalowicz BS, Hodges JS, DiAngelis AJ, Lupo VR, Novak MJ, Ferguson JE, et al. OPT Study. Treatment of periodontal disease and the risk of preterm birth. N Engl J Med 2006;355(18):1885-94.

21. McKinnon M, Luke G, Bresch J, Moss M, Valachovic RW. Emerging allied dental workforce models: considerations for academic dental institutions. J Dent Educ 2007;71(11):1476-91.

22. Insurers cover extra dental cleanings to reduce costs. Kaiser Daily Health Policy Report, March 1, 2007. At: www.kaisernetwork.org/daily_reports/rep_index. cfm?hint=3\&DR_ID=43281. Accessed: May 20, 2008.

23. Hendricson WD, Cohen PA. Oral health care in the $21 \mathrm{st}$ century: implications for dental and medical education. Acad Med 2001;76(12):1181-206.

24. Al-Shammari K, Al-Ansari JM, Moussa NM, Ben-Nakhi A, Al-Arouj M, Wang HL. Association of periodontal disease severity with diabetes duration and diabetic complications in patients with type 1 diabetes mellitus. J Int Acad Periodontol 2006;8:109-14.

25. Khader YS, Dauod AS, El-Qaderi SS, Alkafajei A, Batayha WQ. Periodontal status of diabetics compared with nondiabetics: a meta-analysis. J Diabetes Complications 2006;20:59-68.

26. Moore PA, Zgibor JC, Dasanayake AP. Diabetes: a growing epidemic of all ages. J Am Dent Assoc 2003; 134:11S$15 \mathrm{~S}$.

27. Harris MI, Flegal KM, Cowie CC, Eberhardt MS, Goldstein DE, Little RR. Prevalence of diabetes, impaired fasting glucose, and impaired glucose tolerance in US adults: the third National Health and Nutrition Examination Survey, 1988-1994. Diabetes Care 1998;21:518-24.

28. Janket SJ, Wightman A, Baird AE, Van Dyke TE, Jones JA. Does periodontal treatment improve glycemic control in diabetic patients? A meta-analysis of intervention studies. J Dent Res 2005;84:1154-9.

29. Kornman KS. Patients are not equally susceptible to periodontitis: does this change dental practice and the dental curriculum? J Dent Educ 2001;65(8):777-84.

30. Kunzel C, Lalla E, Albert DA, Yin H, Lamster IB. On the primary care frontlines: the role of the general practitioner in smoking-cessation activities and diabetes management. J Am Dent Assoc 2005;136(8):1144-53.

31. ADEA policy statements. J Dent Educ 2008;72(7): 810-22.

32. American Dental Education Association. Competencies for the new general dentist (as approved by the 2008 ADEA House of Delegates). J Dent Educ 2008;72(7):823-6.

33. Oral health in America: a report of the surgeon generalexecutive summary. Rockville, MD: U.S. Department of Health and Human Services, National Institute of Dental and Craniofacial Research, National Institutes of Health, 2000.

34. National call to action to promote oral health. Rockville, MD: U.S. Department of Health and Human Services, National Institute of Dental and Craniofacial Research, National Institutes of Health, 2003.

35. Field MJ, ed. Dental education at the crossroads: challenges and change. An Institute of Medicine Report. Washington, DC: National Academy Press, 1995:3-4. 
36. Greiner AC, Knebel E, eds. Health professions education: a bridge to quality. Washington, DC: Institute of Medicine of the National Academies of Science, National Academies Press, 2003. At: www.nap.edu/books/0309087236/html/. Accessed: May 22, 2008.

37. Hendricson WD, Anderson E, Andrieu SC, Chadwick DG, Cole JR, George MC, et al. Does faculty development enhance teaching effectiveness? J Dent Educ 2007;71(12):1513-33.

38. Werb SB, Matear DW. Implementing evidence-based practice in undergraduate teaching clinics: a systematic review and recommendations. J Dent Educ 2004;68(9):9951003.

39. Bertolami CN. Creating the dental school faculty of the future: a guide for the perplexed. J Dent Educ 2007;71(10):1267-80.

40. Haden NK, Andrieu SC, Chadwick DG, Chmar JE, Cole JR, George MC, et al. The dental education environment. J Dent Educ 2006;70(12):1265-70.

41. Coormarasamy A, Khan KS. What is the evidence that postgraduate teaching in evidence-based medicine changes anything? A systematic review. Br Med J 2004;329:1017-22.

42. Geissberger MJ, Jain P, Kluemper GT, Paquette DW, Roeder LB, Scarfe WC, Potter BJ. Realigning biomedical science instruction in predoctoral curricula: a proposal for change. J Dent Educ 2008;72(2):135-41.

43. Wilder RS, Thomas KM, Jared H. Periodontal-systemic disease education in United States dental hygiene programs. J Dent Educ 2008;72(6):669-79.

44. Borrell LN, Kunzel C, Lamster I, Lalla E. Diabetes in the dental office: using NHANES III to estimate the probability of undiagnosed disease. J Periodontal Res 2007;42(6):559-65.

45. Silverman S Jr. Demographics and occurrence of oral and pharyngeal cancers: the outcomes, the trends, the challenge. J Am Dent Assoc 2001;132(Suppl):7S-11S.
46. Cannick GF, Horowitz AM, Reed SG, Drury TF, Day TA. Opinions of South Carolina dental students toward tobacco use interventions. J Public Health Dent 2006;66(1): 44-8.

47. Tobacco use and cessation counseling: global health professionals survey pilot study, 10 countries. MMWR Morb Mortal Wkly Rep 2005;54(20):505-9.

48. Genetics and its implications for clinical dental practice and education: report of panel 3 of the Macy Study. J Dent Educ 2008;72(2 Suppl):86-94.

49. Curriculum and clinical training in oral health for physicians and dentists: report of panel 2 of the Macy Study. J Dent Educ 2008;72(2 Suppl):73-85.

50. Clemmens DA, Kerr AR. Improving oral health in women: nurses' call to action. MCN Am J Matern Child Nurs 2008;33(1):10-6.

51. Thomas KM, Jared HL, Boggess K, Lee J, Moos M, Wilder RS. Prenatal care providers' oral health knowledge and behaviors. J Dent Res 2008;87(Spec Iss A):Abstract \#0725.

52. Mouradian WE, Reeves A, Kim S, Evans R, Schaad D, Marshall SG, Slayton R. An oral health curriculum for medical students at the University of Washington. Acad Med 2005;80:434-42.

53. Iacopino AM. The influence of "new science" on dental education: current concepts, trends, and models for the future. J Dent Educ 2007;71(4):450-62.

54. Wilder RS, Robinson C, Jared HL, Lieff S, Boggess K. Obstetricians' knowledge and practice behaviors concerning periodontal health and preterm delivery and low birth weight. J Dent Hygiene 2007;81(4):81.

55. New opportunities for dentistry in diagnosis and primary health care: report of panel 1 of the Macy Study. J Dent Educ 2008;72(2 Suppl):66-72.

56. Fulmer T. New York University College of Nursing takes on the challenge of innovation for the healthcare system. MCN Am J Matern Child Nurs 2008;33(1):7. 